\title{
The Role of Bank Value in Cash Holdings of Banks in Ghana
}

\author{
Samuel Asubonteng and Yusheng Kong
}

\section{ABSTRACT}

The current study explored the influence of bank value on cash holding among universal banks in Ghana. A panel data covering the period from 2009 to 2018 was used for the analysis. The Panel Least square regression model was utilized as the main technique for data analysis. The findings from this study revealed that, bank value has a significant positive influence on cash holdings of the universal banks in Ghana. Similarly, the study showed that, profitability, working capital and growth contribute positively to cash holdings of the banks. It is recommended that the universal banks should focus more on improving the bank value through value addition policies and measures. This will contribute to achieving a greater level of cash holdings. Keeping enough cash helps the banks to take advantage in any business opportunity that may arise at any time.

Keywords: Cash Holdings, Bank Value, Universal Banks, Ghana.
Published Online: January 13, 2021

ISSN: 2507-1076

DOI: $10.24018 /$ ejbmr.2021.6.1.677

Samuel Asubonteng *

School of Finance and Economics, Jiangsu University, China.

(e-mail: asubos22@yahoo.com)

Yusheng Kong

School of Finance and Economics, Jiangsu University, China.

*Corresponding Author

\section{INTRODUCTION}

Bank value and cash holding have become two most important concepts that have received increased attention by researchers in the recent times [1-3]. According to [4], bank value often relates itself to firm value which clearly explains the economical concept under the supervision of multiple value of business. Bank value is the value that a bank is worthy of at a particular period of time. The value of a bank can either be designed on the basis of book value or market value. But as per Allen, Carletti [5], bank value primarily depends on the constitution of market value. Market capitalization enhances the development of market value along with bank value. Market value is calculated as a sum of debts, equity, and minority interest. The future working of market value depends on free cash flow that empowers market capitalization while focusing more on the market development through economic growth.

Mudambi and Puck [6], defined Bank value in such a way that they relate bank value with bank capital and bank liabilities. They were of the opinion that bank value depends upon certain factors and elements which enhance the strength as well as hold of bank finances over the development of the economy. Bank value somehow acts as a supportive material for running the state economy at a moderate rate. Bank capital represents the worth of the bank along with the balance of value. The Study from Sundaresan and Wang [7], says that bank value differs from state to state and from bank to bank. Value also depends on the number of clients and customers per bank, which helps for the growth and development of the bank. Bank assets are also part of the bank value in general. Everything that a bank possess is considers to be a chain of value for a particular bank. The asset sector usually consists of loans, interests, cash, government security, credit cards and much more. According to [8], the bank capital represents the value of banking which considers equity mechanism as an asset that can easily absorb the losses as well as easily manage the losses through different aspects of bank value.

Moreover, Cash holding by banks has been emphasized to play a key role in the banking business. This emphasizes that having enough cash is very important for the banks to meet other important requirements. However, there is a huge opportunity cost for holding more cash. [9]. Grasping sufficient cash is the mainly significant ability accepted by contemporary bank to make available "operational liquidity" as well as to take advantage of good investment chances. Cash Holding is defined as "the cash in hand or readily available for investment in physical assets and to distribute to investors" [10]. In general, organizations grasp capital for a variety of reasons for example to deal with the set requirements of dealing with unexpected capital claims that may have the need of supplementary quantity to be set aside for a bank's security [11]. On the other hand, it is pointed out that the reasons for keeping cash in various sectors is different from each other due to different operations. [12], in their research in Ghana focused on bank value or worth under the perspective of latest model of bank value, which perhaps increases the effectiveness of banking system in Ghana. A study by [13], had findings proving that meaning of bank value is to enhance sustainability value of bank in terms of economics and finance. Previous studies by [14], believes that past Ghanaian governments attempted to use Ghana's well developed banking system to grow the financial system but in fact awful loans and debts caused the downfall of these 
banks in Ghana due to major losses during the late 1980's which causes the rise in bank external loans.

The study by [15], believes that there are a lot of empirical evidences available that shows the inefficiency of the banking system when the Ghanaian banks faced large amount of losses due to poor banking performance. Whereas bank indicators showed poor performance which include deprived value loans and different level of acclaim risk as well as threats to private agents, it includes restricted or unsatisfactory capitalization, high rank of liquidity threat, many occurrences of bad loans and inefficiencies. Empirical evidences state that there are very fever studies based on the Ghana bank value and system focusing on its finance sector. The limited literature on this area of study has led the authors to conduct the current study on the bank value and cash holding condition of banks in Ghana as a West African country. More research should also be conducted especially in the field to test the need of reforms in different finance sectors on bank value and also about its poor performance in the sub-region. According to studies [12], the bank productivity and profitability with the composition of reforms works according to different banking policies and strategies.

According to past studies [16] development in the banking system indicates vigorous asset development and improved functionality of bank performance. Studies by [17], also elaborates some findings regarding bank value construction in Ghana, which reflects the inefficiency in structural and policies that greatly contributes to the high cost of Ghanaian bank investment. As per research study [18], Ghanaian banks are unable to reach to the highest rates of achieving bank value as compare to other countries of Africa due to its low geographical location that hinders rising of bank investment across the country, as due to bad location, Ghanaian banks are unable to facilitate customer value as the customer value is decreasing because of its geographical area. The study by [19], analyzed that Ghanaian banks were unable to compete with the intervention of foreign banks because of its weak foreign policies and insufficient banking strategies.

If perfect market conditions are under consideration, then at this point it could be said that the value of the bank is not related by any means to the bank cash holding. It is a matter of fact that in such situations whenever the bank will be under any kind of financial constraints the bank can liquidate all of its quick assets in order to drag itself out of the situation of the financial constraint since the quick assets are there for the purpose of highest liquidity speed. All of the assets that can be traded quickly and that could generate cash quickly are involved in the quick assets bracket. This concept is based on the perfection of a market. Here, a bank will rapidly squeeze cash from all of its assets if they could be quickly converted into cash and the bank could afford to pay the long term outstanding debt, its current financial obligations and all of the things that are putting constraints on the growth and development of the bank. However, in a real world situation it could be seen that the market is never perfect but rather the market conditions always put constraint on the firms. According to the tradeoff theory the value of the bank is made by the amount of check and balance in its cost versus benefit relationships. This can be justified by creating a real time scenario that the bank will be leading in the market only upon the condition where it will be earning high profits. A bank will earrn a good place in the market only when the amounts of losses are less, and the amounts of profits and returns are higher. So, the question that is begging for answer is; what will happen if the bank fails to maintain a good balance between costs and benefits? It is very clear that whenever a bank will not maintain the certain balance good enough to facilitate the operations, its value in the market will drop. A drop in market value will not only put the bank in a downtrodden condition but will also impact all of its stakeholder base, this will also impact the functioning of the bank and as well impact the market value and market position of the bank. It is clear that when a bank will not be paying properly to its stakeholders, they will draw back from the bank. It is also clear that the bank will start to lose its customers. So, this theory is proposing that cash holding is a very important factor in order to create bank value. This theory again proposes that bank cash holding is the demand of the bank value as it cannot be created without holding proper reserves and proper backups.

To restore these confidences in the universal banks in Ghana, several policies and programs have been developed to improve the bank value but as to how the bank value contributes to cash holdings of these banks remained limited in research. Based upon this argument, this study examines how bank value contributes to cash holdings among the universal banks in Ghana.

\section{EMPIRICAL LITERATURE}

Financial value relates to what business offers to its shareholders, in terms of profitability, revenue growth, value to shareholders and return on Investment. Internal perspective indicates the internal procedure related to business, i.e., service quality, product quality, production efficiency, cost efficacy and recycling time. The perspective of the customer not only related to customer wants, needs, or satisfaction, but also market share, i.e., level of satisfaction, the level of the service. Learning and innovation perspective relates to those factors that are essential for the organization to serve in the future; i.e. assets, employees' satisfaction, and innovation for market $[2,20,21]$. It is crucial to select the measurement of bank value according to the nature and size of the organization, thus, this study gets help from the literature to finalize the measuring. Value could be said to depend on the number of clients and customers per bank, who help in the development of banking system. Bank assets are also part of the bank value in general. Everything that a bank possess is considers to be a chain of value for a particular bank. The asset sector usually consists of loans, interests, cash, government security, credit cards and much more. Perhaps the liability portion depends on the continuous function of loans, debts, and loss through debts. Bank's capital acts as the supporting body for the creditors when sometimes bank is out of its assets. Sundaresan and Wang [7] represented a dynamic continuous-time model related to the finest features of bank liabilities plus few favorable features of bank capital involving bank productivity and bank value. This liability formation integrates liquidity services like deposits, debts, loans, deposit insurance, capital investment and necessity, and various system defaults. This model 
basically, allows the formation for the enhancement of automatic deposits to the insured bank so that it can maximize the value through combining with non-deposit debt and to show equity in its liability structure. This model as a result, collaborates the organization of banking with its assets, which gradually help in the growth of bank value. This model maximizes the bank balance by increasing its value through deposits and non-deposits debt so that endogenous defaults may correspond with the dogmatic end. Bank value coincided with the balance in deposits and nondeposits debt. Through this response, banking system could be changed, or changes can be regulated. According to [8] the bank capital represents the value of banking which considers equity mechanism as an asset that can easily absorbs the losses as well as bank can be able to easily negotiate the losses through different aspects of bank value. Bank capital is considered in this scenario as the coin whose one side shows the picture of bank assets while other side shows the picture of bank liabilities. A Study by Maika and Latifah [22] believes that the concept of bank value relies on the specific international standards which can rather vary from one bank to another bank, but as per Basel III capital regulators depend on certain tiers. Tier 1 and tier 2 represent the strength of bank capital because it is able to hold all of banks accumulated funds. These funds on the other hand are used to prevent bank from collapsing or shutting down while after facing a great loss, it enables it to maintain proper functioning of the bank. Shareholders equity, commonly known as a bank capital also helps in the maintenance of bank value. According to [4] bank value often relates itself to firm value which clearly explains the economical concept under the supervision of multiple value of business.

There are many different factors that can lead to different levels of cash holding, such as development opportunities, Corporate Governance of the bank, financial policy and financial conditions of the country. The opportunity to develop a stronger market base is crucial for cash holding. A study used the sample of 1121 banks in UK to determine the factors of cash holding and shows that opportunity growth, assets liquidation, cash flow, leverage and debt of banks are vital to determine the cash holding. Another study concludes the same results in US by using the sample of 1048 commercial banks to ascertain the association between opportunity growth and cash holding. Joseph, Ocasio [23], investigated the empirical determinants of bank cash holdings for a sample of UK banks and the results revealed that banks' growth opportunities, cash flows, liquid assets, leverage and bank debt are important in determining cash holdings. Kuo and Hung [24], made the same conclusion about the relationship between growth opportunities and cash holding by collecting data from 1048 publicly traded US banks from 1971 to 1994 to find the determinants of bank cash holdings. After testing the time series and cross-section data, the study realized that with cash growth and risk of cash flow, banks get the highest amount of cash than non-cash assets. The banks that get the most accessible in capital markets reduces the proportion of the cash holding. A study also determined the level of cash holding based on a panel data of 125 sample of American banks to investigating the relationship and concluded that investment opportunities are more associated with cash holding level. They also believe that growth of banks enables them to have more liquidity. According to Johnson, Schnatterly [25], banks that grow rapidly keep more cash. A study used a sample of 50 Public Limited non-financial banks listed on Karachi Stock Exchange over the period of 2012 to 2014 and concluded that bank size significantly affects the bank cash holdings. However, debt structure, leverage and Return on Asset are non-significant and have a negative association with cash holdings. [26], examined the factors inducing the cash holdings of REITs by using Ordinary Least Square (OLD) method. They analyzed a sample of 1114 observations for 194 "real estate investment trusts" (REITS) in the US from 1998 and 2006. The results showed that cash holdings of REITS have a negative relationship with funds from operations, leverage, and advertisement. It is proven from literature that the interest of most researchers are currently focusing on the relationship between cash holding and bank value. The study by [27], shows that the performance of the bank is dynamically influenced by bank's policies and bank's cost. According to [28], compared to other investments, the cost of opportunity due to low income is more than having more income and this could lead the banks to maintain less hold of cash. According to [29], large cash holdings can increase the agency's dispute between pool managers and acquisitions because the managers can lose totally on noncompensation investment. Cash holdings is influenced by many factors such as the country's economic and lawful environment, banks 'financial strategy, banks' financial situation and government structure. According to the study on China-based banks, cash holding features are different from US banks. Therefore, it is difficult to decide if Chinese banks have more agency problems than the agency cost of US banks [27, 30-33]. [34] compared the strongest price of US industrial institutions from 2001 to 2005, and asserted that the effectiveness of cash holding in banks could be realized in high bank value. [35], used panel data of public listed banks to examine the cash holdings and bank value for a sample of Brazilian institutions and its results showed that a lot of cash holdings leads to more increase in banks' value. Another research paper takes data from the latest database of US for assessing the relationship between cash holding and bank value. This paper analyzes how a model for American banks in holding cash could influence banks' value by considering a year span from1999 to 2005. A study also found the relationship between market to book value as significant with banks' cash holding [36]. There are very few studies which have investigated and found direct relationship between Banks' Value and Cash Holding. So, it becomes necessary in the present time to examine this relationship especially in the context of Ghana, where in the best knowledge of the authors, no single study is available which directly investigate the relationship of bank cash holding and banks value.

\section{MethodOLOGY}

This study investigates the influence of Bank Value on cash holdings of universal banks in Ghana using a panel data covering a period from 2009 to 2018. In this paper, correlation analysis, and panel least square regression and robust least square regression analyses were conducted. The 
correlation test was performed in order to evaluate the magnitude of the association among the variables [37]. The correlation analysis is a statistical technique used for the evaluation of the strength of association among the variables. The key technique employed for the analysis was the panel least square regression method. A panel least squares approach is applied when the data consists of both time series and cross-sections. The various assumptions of OLS regression were met hence finally the regression equation was estimated to evaluate the impact of bank governance dimensions on cash holding of universal banks.

CASHHOLD $_{i t}=\alpha_{i}+\beta_{1}$ Profit $_{i t}+\beta_{2}$ workingcapital $_{i t}+$ $\beta_{3}$ Bankvalue $_{, i t}+\beta_{4}$ Banksize $_{i t}+\beta_{5}$ Growt $_{i t}+\beta_{6}$ Cashflow $_{\text {it }}+\varepsilon_{i t}$

The dependent variable used in the study was Cash holding (CASHHOLD) which was measured as the assets kept in the form of ready cash by the business proprietor or company so that it can be spent rather than invested [38]. The explanatory variables included Bank Value measured by Tobin's Q is defined as the ratio between the market value and replacement value of a tangible asset. The control variables included the Cash Flow (Cash flow), which was measured as the amount of money coming in and going out of the bank business while Profitability was measured as the ability of a company to generate revenue by using its resources that is in excess of expenses. Likewise, Growth is estimated as the growth in sales ratio over the growth in asset ratio. This helps us to know which bank has greater chances of investment growth. The greater and faster the bank grows the greater its performance and valuation $[39,40]$. Similarly, Bank size (Banksize) which is measured upon the basis of the total assets it holds and its overall revenues [41]. The variable Working capital (Workcap) represents the capital of the banks measured as the capital of a business that is utilized in daily operations. It is calculated by subtracting the current liabilities from the current assets on specific date [42].

\section{RESUlts AND DisCUSSION}

The study sought to explore the influence of bank value on cash holding among universal banks in Ghana. A panel data covering the period from 2009 to 2018 was used for the analysis. The results from the panel unit roots test suggest that, most of the variables used for the study were stationary at first difference hence the variable was transformed and analyzed at their first difference. The results from the descriptive statistics show that, all the variables except Cash flow have positive mean values with minimum standard deviations ranging from 0.07-10.186 (See Table 1).

The correlation analysis was further used to establish the association between the dependent (Cash Holdings) and the independent variables (Bank value, profitability, Working Capital, Bank Size, Growth and Cash Flow). The results show that, there is a strong positive relationship between cash holdings and Profitability( $(\mathrm{r}=0.7847)$, Working Capital $(\mathrm{r}=0.717)$, Bank Value $(\mathrm{r}=0.824)$ and Bank size $(\mathrm{r}=0.706)$. However, the results show that, cash holdings has very weak but positive correlation with Growth $(\mathrm{r}=0.018)$ and Cash Flow (0.033). The results imply that, the increase in the banks' profitability, working capital and Bank value increase the cash holdings for the universal banks considered for the study. Similarly, the results demonstrate that, increase in cash flow and growth of the banks contributes to cash holding among the banks (See Table 2).

\begin{tabular}{cccccccc}
\multicolumn{7}{c}{ TABLE 1: DESCRIPTIVE STATISTICS } \\
\hline Statistics & Cash Holding & Profitability & Working Capital & Bank Value & Bank size & Growth & Cash Flow \\
\hline Mean & 0.013133 & 0.023092 & 0.022610 & 0.812811 & 0.186024 & 0.000578 & -0.001727 \\
Median & 0.020001 & 0.000000 & 0.070000 & 0.100000 & 0.070000 & 0.00000 & -0.011000 \\
Maximum & 6.250000 & 7.349999 & 7.250000 & 41.17000 & 8.420000 & 0.617000 & 0.554000 \\
Minimum & -9.110001 & -10.24000 & -10.80000 & -43.23000 & -11.36000 & -0.508000 & -0.632000 \\
Std. Dev. & 1.196068 & 1.448467 & 1.552820 & 10.18650 & 1.402642 & 0.074286 & 0.123299 \\
Observations & 249 & 249 & 249 & 249 & 249 & 249 & 249 \\
\hline
\end{tabular}

\begin{tabular}{lccccccc}
\multicolumn{7}{c}{ TABLE 2: CORRELATION ANALYSIS } \\
\hline \multicolumn{1}{c}{ Variable } & 1 & 2 & 3 & 4 & 5 & 6 & 7 \\
\hline 1. Cash Holdings & 1 & & & & & & \\
2. Profitability & 0.7847 & 1 & & & & & \\
3. Working capital & 0.7168 & 0.6492 & 1 & & & & \\
4. Bank Value & 0.8240 & 0.0882 & -0.0600 & 1 & & & \\
5. Bank size & 0.7058 & 0.5764 & 0.6357 & -0.0322 & 1 & & \\
6. Growth & 0.0179 & -0.0017 & -0.0324 & 0.0482 & -0.0436 & 1 & \\
7. Cash Flow & 0.0325 & -0.0140 & -0.0455 & 0.0658 & -0.0442 & -0.0234 & 1 \\
\hline
\end{tabular}

The study utilized the panel least square regression analytical method to examine the influence of bank value on cash holdings of universal banks used for the study. The results of the panel least square regression model show that, the R-square value 0.762 demonstrate a high explanatory power of the model. This implies that, about $76.2 \%$ of the changes in the dependent variable (cash holding) is explained by the model same as the F-statistics $(\mathrm{F}=23.256, \mathrm{P}<0.001)$ indicating that the overall model impact is statistically significant at $1 \%$ level. Results from Table 3 show that, Bank Value $(\beta=0.014, \mathrm{P}<0.01)$ has statistically significant positive influence on cash holding. This implies that, increase in Bank value increases cash holdings of the banks while a decline in the bank value also reduces cash holdings. The coefficient of the bank value variable implies that, $1 \%$ change in the bank value results in $0.014 \%$ change in cash holding of the universal banks. Bank value measured as the ratio between the market value and replacement value of a tangible asset has a positive impact on cash holdings.

Results from Table 3 again demonstrate that, profitability $(\beta=0.399, \mathrm{P}<0.01)$, working capital $(\beta=0.156, \mathrm{P}<0.01)$, Bank size $(\beta=0.256, \mathrm{P}<0.01)$ and Cash flow $(\beta=0.7131, \mathrm{P}<0.01)$ have statistically significant and positive influence on cash holding. The findings suggest that, increase in profitability, 
working capital, bank size and cash flow of the universal banks contributes to improving the cash holdings on the universal banks.

\begin{tabular}{ccccc}
\multicolumn{5}{c}{ TABLE 3: RESULTS FROM PANEL LEAST SQUARE REGRESSION } \\
\hline Variable & Coefficient & Std. Error & t-Statistic & Prob. \\
\hline$\triangle$ Profitability & 0.399732 & 0.115282 & 3.467438 & 0.0006 \\
$\triangle$ Working capital & 0.155987 & 0.056493 & 2.761157 & 0.0063 \\
$\triangle$ Bank Value & 0.013600 & 0.003847 & 3.535654 & 0.0005 \\
$\triangle$ Bank size & 0.256543 & 0.037298 & 6.878265 & 0.0000 \\
$\triangle$ Growth & 0.166331 & 0.258859 & 0.642556 & 0.5212 \\
$\triangle$ Cash Flow & 0.713073 & 0.203325 & 3.507055 & 0.0006 \\
C & -0.035159 & 0.031306 & -1.123054 & 0.2627 \\
R-squared & 0.761929 & & & \\
Adjusted R-squared & 0.729167 & & & \\
F-statistic & 23.25648 & & & \\
Prob(F-statistic) & 0.000000 & & & \\
\hline
\end{tabular}

Table 4 presents the findings from the robust panel regression to support the analysis of the influence of bank value on cash holdings of universal banks. The model statistics show that, $\mathrm{R}$-square $\left(\mathrm{R}^{2}=0.426\right)$, Deviance (42.110) which implies that, about 42.6 percent of the changes in the dependent variable (cash holdings) are explained by the model. The results indicate that, Bank value $(\beta=0.0054$, $\mathrm{P}<0.01)$ has statistically significant positive impact on cash holding of the universal banks. This analysis also supports that of the panel least square regression results in Table 3. The results from the robust analysis portray that, $1 \%$ increase in the bank value also increases the cash holdings by $0.0054 \%$.

Similarly, Table 4 show that profitability $(\beta=0.235$, $\mathrm{P}<0.01)$, working capital $(\beta=0.383, \mathrm{P}<0.01)$, Bank size $(\beta=0.214, \mathrm{P}<0.01)$ and Cash flow $(\beta=0.419, \mathrm{P}<0.01)$ also have statistically significant and positive influence on cash holding. The results from the two analyses namely Pane least square regression and robust regression are almost the same. However, the explanatory power from the Panel Least square regression remains higher than that of the robust regression.

\begin{tabular}{ccccc}
\multicolumn{5}{c}{ TABLE 4: RESULTS FROM ROBUST PANEL REGRESSION } \\
\hline Variable & Coefficient & Std. Error & Z-Statistic & Prob. \\
\hline$\triangle$ Profitability & 0.235172 & 0.018382 & 12.79383 & 0.0000 \\
$\triangle$ Working & 0.383549 & 0.018017 & 21.28775 & 0.0000 \\
capital & 0.005423 & 0.001917 & 2.828740 & 0.0047 \\
$\triangle$ Bank Value & 0.214073 & 0.018450 & 11.60310 & 0.0000 \\
$\triangle$ Bank size & 0.159154 & 0.258506 & 0.615667 & 0.5381 \\
$\triangle$ Growth & 0.418727 & 0.155894 & 2.685974 & 0.0072 \\
$\triangle$ Cash Flow & -0.031029 & 0.019444 & -1.595819 & 0.1105 \\
C & Robust Statistics & & 0.411920 \\
R-squared & 0.426147 & Adjusted R-squared & 0.876385 \\
Rw-squared & 0.876385 & Adjust Rw-squared & 396.0781 \\
Akaike info & 365.9989 & Schwarz criterion & 0.343227 \\
criterion & 42.10996 & \multicolumn{2}{c}{ Scale } \\
Deviance & \multicolumn{5}{c}{}
\end{tabular}

The study contributes that bank value has a significant influence on cash holding. The results highlight that, increase in bank value has a positive influence on cash holdings. As the bank value increase, the bank keeps more cash for future investment. The findings from this study are in line with previous scholars such as [36], who also concluded that, bank value has a positive influence on cash holdings of banks. The findings from this study are further in line with previous studies such as Kuo and Hung [24], who found that cash flow and growth have significant influence on cash holding of banks. Obviously, the findings of this study ascertain that with bank growth and adequate amount of cash flow, banks get the chance to keep high amount of cash holding. The banks that get the most accessible in capital markets reduces the proportion of the cash holding of unconnected assets. As the banks grow, they are able to keep more cash in the banks which support the findings that, increase in growth of the banks tend to increase the cash holdings while similar decrease in growth reduces the cash holding of the banks. Again, the results agree with scholars who also believe that growth of banks results in more liquidity in cash holding. According to Johnson, Schnatterly [25], banks who grow rapidly keep more cash. Bank value should play an important role in the banking business which needs to be given both managerial and operational attention. This study then concludes that, universal banks in Ghana should consider that bank value forms an important component and a crucial factor to make their banks competitive and profitable.

\section{CONCLUSIONS}

The relationship that has been studied in the current study is the bank value's impact on cash holdings of the universal banks in Ghana. The bank value has been taken as Tobin Q value. The impact of this variable is found as positive as well as significant on cash holdings. It must be noted here that one of the basic goals of a bank is to make sure that the financial matters go as smoothly as possible. The bank might require funds from outside the bank but sometimes the outside funds are not available and even when they are available, they are very expensive. In these conditions, the banks might have to let go the investment opportunities due to shortage of money, but cash holdings might provide solution to the bank in this case. The value of the bank might play an important role in this regard as the greater market value will provide more investment opportunities and the external fund might also be easily available in this circumstance. Based on the significant impact of bank value on cash holdings, it can be concluded that Ghana banks must make sure that the ratio of their market value to their asset value remains favorable enough to maintain the cash holdings for the company. The study also concludes that, banks' profitability, growth, cash flow and bank size have important role to play in the context of cash holdings in the banks.

Based on this, it is recommended that the universal banks should focus more on improving the bank value through value addition policies and measures. This will contribute to achieving a greater level of cash holdings. Keeping enough cash helps the banks to take advantage in any business opportunity that may arise at any time. The cash holding has implications for the policies such that it seems to be a very important part of the policies if their aim is to enrich the firms with the knowledge of financing and financing choices. According to this perspective, recommendations can be made for the policy. Firstly, most of the universal banks in Ghana are more focused on the economic value added, cash flows, earnings that leads to the efficiency and effectiveness of the banking sector. Hence, firms must manage and settle their policies in ways that can enhance their potential in dealing with Net Interest Margin. The literature in these domains had revealed that the cash flows and the earnings together are 
highly dependent on Net Interest Margin, the changes in which can decrease the efficiency of banking sector. In this case, the government and the Central Bank must involve measures that are very controlled and accurate regarding the income, monetary and fiscal policies. These institutions are the main representative of the viable and prominent economic policies which can be enabled to exercise a measurable and significant control on the rate of Inflation and also affects the Real GDP by having a control on these variables. This way they can have better understanding of the issues that arise and how they impact the economy and the performance of the universal banks. Banks must also make policies regarding joint efforts with the Central Bank so that they can devise ways of creating and adopting innovative schemes and ideas for active management of the banks.

\section{ACKNOWLEDGMENT}

This paper is supported by The National Natural Science Foundation of China with grant number 71371087.

\section{REFERENCES}

[1] Ondieki, W.M., Factors influencing stakeholders' participation in monitoring and evaluation of Local Authority transfer fund projects in Kisii municipality, Kenya. 2011, University of Nairobi, Kenya.

[2] Sintset Kenfac, G., S. Nekoumanesh, and M. Yang, Process Innovation: Impacts on Organization's Performance: A Qualitative Study of Four Swedish Municipalities. 2013.

[3] Iqbal, N., A framework for assessing the impact of investment in human capital development on organisational performance. 2013.

[4] García-Meca, E., I.-M. García-Sánchez, and J. Martínez-Ferrero, Board diversity and its effects on bank performance: An international analysis. Journal of Banking \& Finance, 2015. 53: p. 202-214.

[5] Allen, F., E. Carletti, and R. Marquez, Deposits and bank capital structure. Journal of Financial Economics, 2015. 118(3): p. 601-619.

[6] Mudambi, R. and J. Puck, A global value chain analysis of the 'regional strategy'perspective. Journal of Management Studies, 2016. 53(6): p. 1076-1093.

[7] Sundaresan, S.M. and Z. Wang, Bank liability structure. Columbia Business School Research Paper, 2017(14-41).

[8] Haq, M., N.K. Avkiran, and A. Tarazi, Does market discipline impact bank charter value? The case for Australia and Canada. Accounting \& Finance, 2019. 59(1): p. 253-276.

[9] Kusnadi, Y., Do corporate governance mechanisms matter for cash holdings and firm value? Pacific-Basin Finance Journal, 2012. 19(5): p. 554-570.

[10] Shah, A., The corporate cash holdings: Determinants and implications. African Journal of Business Management,, 2012.

[11] Damodaran, A., Dealing with cash, cross holdings and other nonoperating assets: Approaches and implications". Cross Holdings and Other Non-Operating Assets: Approaches and Implications, 2015.

[12] Alhassan, A.L. and N. Asare, Intellectual capital and bank productivity in emerging markets: evidence from Ghana. Management Decision, 2016. 54(3): p. 589-609.

[13] Mensah, L., et al., Bank Risk Control and Shareholder Value Creation: The Case of Ghana. African Journal of Management Research, 2016. 24: p. 2-14.

[14] Adusei, M., Bank profitability: Insights from the rural banking industry in Ghana. Cogent Economics \& Finance, 2015. 3(1): p. 1078270.

[15] Acharya, A. and T. Hilton, Assessing Value for Money in Integrated Development Programmes-The Case of a Millennium Villages Project in Northern Ghana. 2018.

[16] Baoko, G., I.A. Acheampong, and M. Ibrahim, Determinants of bank credit in Ghana: A bounds-testing cointegration approach. African Review of Economics and Finance, 2017. 9(1): p. 33-61.

[17] Antwi, J.O., et al., Assessing the human resource management practices of public banks from employees' perspective: case study of selected branches of Ghana commercial bank, Kumasi. Global Journal of Human Resource Management, 2016. 4(1): p. 13-30.
[18] Nygaard, I. and S. Bolwig, The rise and fall of foreign private investment in the jatropha biofuel value chain in Ghana. Environmental Science \& Policy, 2018. 84: p. 224-234.

[19] Asumadu-Sarkodie, S. and P.A. Owusu, The impact of energy, agriculture, macroeconomic and human-induced indicators on environmental pollution: evidence from Ghana. Environmental Science and Pollution Research, 2017. 24(7): p. 6622-6633.

[20] Kaplan, R.S. and D.P. Norton, Using the balanced scorecard as a strategic management system. 1996.

[21] Saeidi, S.P., et al., How does corporate social responsibility contribute to firm financial performance? The mediating role of competitive advantage, reputation, and customer satisfaction. Journal of business research, 2015. 68(2): p. 341-350.

[22] Maika, M.R. and F.N. Latifah, Exploring Selling Feature vs Selling Value Toward Saving at Sharia Bank. Universitas Muhammadiyah Sidoarjo, 2017.

[23] Joseph, J., W. Ocasio, and M.-H. McDonnell, The structural elaboration of board independence: Executive power, institutional logics, and the adoption of CEO-only board structures in US corporate governance. Academy of Management Journal, 2014. 57(6): p. 1834-1858.

[24] Kuo, Y.P. and J.H. Hung, Family control and investment-cash flow sensitivity: Moderating effects of excess control rights and board independence. Corporate Governance: An International Review, 2012. 20(3): p. 253-266.

[25] Johnson, S.G., K. Schnatterly, and A.D. Hill, Board composition beyond independence: Social capital, human capital, and demographics. Journal of management, 2013. 39(1): p. 232-262.

[26] Harford, J., S. Klasa, and W.F. Maxwell, Refinancing risk and cash holdings. The Journal of Finance, 2014. 69(3): p. 975-1012.

[27] Erkens, D.H., M. Hung, and P. Matos, Corporate governance in the 2007-2008 financial crisis: Evidence from financial institutions worldwide. Journal of corporate finance, 2012. 18(2): p. 389-411.

[28] Dumitrescu, E.-I. and C. Hurlin, Testing for Granger non-causality in heterogeneous panels. Economic modelling, 2012. 29(4): p. 14501460.

[29] Jensen, J.M., The Governors' Lobbyists: Federal-State Relations Offices and Governors Associations in Washington. 2016: University of Michigan Press.

[30] Chen, C.H. and B. Al-Najjar, The determinants of board size and independence: Evidence from China. International Business Review, 2012. 21(5): p. 831-846.

[31] Chen, Y., Y. Liu, and J. Zhang, When do third-party product reviews affect firm value and what can firms do? The case of media critics and professional movie reviews. Journal of Marketing, 2012. 76(2): p. 116-134.

[32] Claessens, S. and B. Yurtoglu, Corporate governance and development: An update. 2012: World Bank.

[33] Crowther, D. and G. Lancaster, Research methods. 2012: Routledge

[34] Coccorese, P. and S. Shaffer, Cooperative banks and local economic growth. Regional Studies, 2020: p. 1-15.

[35] Tilahun, W., Assessment of the Effectiveness of Performance Appraisal System: The Case at Dashen Bank Head Office and Five Branches, Ethiopia. 2016, St. Mary's University.

[36] Blunch, N., Introduction to structural equation modeling using IBM SPSS statistics and AMOS. 2012: Sage.

[37] Webster, A., Applied statistics for business and economics. 1992: Irwin Homewood, IL.

[38] Martínez-Sola, C., P.J. García-Teruel, and P. Martínez-Solano, Corporate cash holding and firm value. Applied Economics, 2013. 45(2): p. 161-170.

[39] Durnev, A. and E. Kim, To steal or not to steal: Firm attributes, legal environment, and valuation. The Journal of Finance, 2005. 60(3): p. 1461-1493.

[40] Klapper, L.F. and I. Love, Corporate governance, investor protection, and performance in emerging markets. Journal of corporate Finance, 2004. 10(5): p. 703-728.

[41] Waresul Karim, A., T. van Zijl, and S. Mollah, Impact of board ownership, CEO-Chair duality and foreign equity participation on auditor quality choice of IPO companies: evidence from an emerging market. International Journal of Accounting \& Information Management, 2013. 21(2): p. 148-169.

[42] Mathuva, D., The Influence of working capital management components on corporate profitability. 2015. 